\title{
Increased gut permeability in newborns with food allergy
}

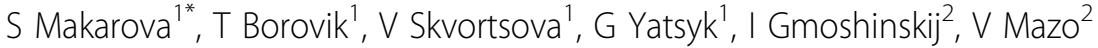 \\ From Food Allergy and Anaphylaxis Meeting (FAAM 2013) \\ Nice, France. 7-9 February 2013
}

\section{Background}

Gut barrier condition is very important factor for development of food tolerance. In the first few years of life, humans gradually develop an intricate balance between tolerance and immune reactivity in the gut mucosa.

Increased absorption of food antigens in early childhood may play role for sensitization and development of food allergy in the future. The purpose of the study is investigation of gut permeability in newborn infants with first symptoms of allergy.

\section{Methods}

51 breastfed newborns were under examination. Human milk $\alpha$-lactalbumin was measured in blood serum by ELISA after breast milk feeding. Index of absorption was calculated according to the amount of consumed breast milk. Gut permeability was assessed twice, at 5-7 and 25-30 days of life.

\section{Results}

Examination atthe age of 5-7days of life revealed that newborns had high level of absorption of human milk $\alpha$ lactalbumin. At 25-30 days of life non-allergic infants had shown a 4- fold reduction of gut permeability during the first month of life regardless of gestation age and the type of feeding. But, it was found that absorption of human milk $\alpha$-lactalbumin did not decrease in $60 \%$ of infants with allergic symptoms appeared during the first month after birth $(\mathrm{p}<0,01)$ and in $35,7 \%$ of malnourish infants with diarrhea syndrome $(\mathrm{p}<0,01)$.

\section{Conclusion}

Patients with early allergic symptoms have increased gut permeability for proteins incomparison to non-allergic infants. So, management of these patients has to include

${ }^{1}$ Scientific Center of Children's Health, RAMS, Moscow, Russian Federation Full list of author information is available at the end of the article measures to reduce theoral uptake of allergens, such as maternal diet and using of hydrolysed formulas.

\section{Disclosure of interest}

None declared.

\section{Author details}

${ }^{1}$ Scientific Center of Children's Health, RAMS, Moscow, Russian Federation. ${ }^{2}$ Institute of Nutrition, RAMS, Moscow, Russian Federation.

Published: 25 July 2013

doi:10.1186/2045-7022-3-S3-P94

Cite this article as: Makarova et al:: Increased gut permeability in newborns with food allergy. Clinical and Translational Allergy 2013 3(Suppl 3):P94.
Submit your next manuscript to BioMed Central and take full advantage of:

- Convenient online submission

- Thorough peer review

- No space constraints or color figure charges

- Immediate publication on acceptance

- Inclusion in PubMed, CAS, Scopus and Google Scholar

- Research which is freely available for redistribution
( Biomed Central

\section{Ciomed Central}

